\title{
Pengembangan Bimbingan Belajar Berbasis Lingkungan di MIM Juwiran, Juwiring, Klaten
}

\author{
Ryan Rizki Adhisa ${ }^{1,}$ Muhammad Arfian ${ }^{2}$, Gilang Cahyo Purnomo ${ }^{3}$, Virtu Femma Virgina ${ }^{4}$, Lina \\ Azhar $^{5}$, Widya Kusumawati ${ }^{6}$, Venia Dwi Wandira ${ }^{7}$, Tri Handayani ${ }^{8}$, Emilya Nur Hidayanti ${ }^{9}$, Farida \\ Tri Handayani ${ }^{10}$ \\ 1,2,3,4,5,6,7,8,9,10 Fakultas Keguruan dan Ilmu Pendidikan, Universitas Muhammadiyah Surakarta, Indo- \\ nesia
}

\section{INFORMASI ARTIKEL}

Histori Artikel:

Submit: 18 Mei 2020

Revisi: 1 Juni 2020

Diterima: 25 Juni 2020

Publikasi: 30 Juni 2020

Periode Terbit: Juli 2020

\section{Kata Kunci:}

bimbingan belajar,

kemampuan akademik siswa,

prestasi siswa

\section{Correspondent Author:}

Ryan Rizki Adhisa

Program Studi Pendidikan Teknik

Informatika,

Fakultas Keguruan dan Ilmu Pendidikan

Universitas Muhammadiyah Surakarta,

Indonesia

Email: ryan.adhisa@ums.ac.id

\begin{abstract}
ABSTRAK
Setiap siswa berhak untuk memiliki prestasi dan kemampuan akademik yang baik. Siswa dalam mencapai keberhasilan tersebut, membutuhkan dorongan dari dalam diri siswa dan dari luar dirinya. Bimbingan belajar merupakan salah satu usaha untuk mendorong siswa mencapai prestasi yang baik. Siswa di Desa Juwiran, kecamatan Juwiring, Klaten menunjukkan semangat belajar yang tinggi, akan tetapi masih kurang dukungan dan dorongan dari luar pribadi siswa. Kedua faktor tersebut, harus terpenuhi guna meningkatkan hasil belajar dan tingkat percaya diri siswa secara optimal. Kegiatan bimbingan belajar yang diadakan secara rutin dapat membantu siswa menyelesaikan permasalahan belajar mereka, melalui metode pembelajaran yang serius namun santai dan menyenangkan. Pengabdian ini dilaksanakan mahasiswa di posko KKNDik FKIP UMS Desa Juwiran. Kegiatan ini efektif membantu meningkatkan pemahaman siswa terhadap materi pelajaran yang telah diberikan di sekolah, meningkatkan hasil belajar siswa, dan juga rasa percaya diri saat mengikuti pelajaran.
\end{abstract}

\section{Pendahuluan}

Siswa memiliki kemampuan akademik yang beragam. Setiap siswa memiliki hak untuk mendapatkan hasil belajar yang memuaskan dan membanggakan. Dilandasi dengan perbedaan yang dimiliki siswa mulai dari perbedaan minat, bakat atau keterampilan, dan kemampuan kognitif khususnya pada bidang akademik. Perbedaan tersebut merupakan hal yang harus diperhatikan oleh sekolah tempat siswa menimba ilmu, karena hasil yang maksimal akan dicapai apabila siswa dapat mengikuti pembelajaran dengan baik sesuai dengan landasan kemampuan dan bakatnya.

Pada bidang akademik, sekolah merupakan lembaga yang dapat mengasah perbedaan kemampuan siswa tersebut. Namun, hal yang terlihat dilapangan adalah, sekolah menyamaratakan proses bimbingan terhadap kemampuan siswa. Dampak yang ditimbulkan adalah terjadinya ketimpangan antara siswa yang memiliki kemampuan akademik tinggi dan siswa yang memiliki kemampuan akademik rendah. Sekolah akan fokus pada capaian siswa dengan akademik tinggi dan menjadikan hal tersebut sebagai suatu standar.

Pihak sekolah melalui guru seharusnya memahami hal tersebut dan dapat menyesuaikan proses pembelajaran yang dilakukan sesuai dengan kondisi masingmasing siswa karena kreativitas guru dalam proses mengajar dapat berpengaruh secara langsung pada 


\section{doi: 10.23917/bkkndik.v2i1.10783}

pemahaman siswa terhadap materi pelajaran (Rasam et al., 2018; Sabardila et al., 2020).

Demi mendorong seluruh siswa agar dapat memiliki kemampuan akademik yang baik, dorongan dari dalam dan luar diri siswa juga harus menjadi perhatian. Dorongan internal adalah dorongan dari dalam diri siswa, seperti kemampuan kognitif dan semangat belajar siswa. Adapun, dorongan dari luar ialah pengaruh lingkungan dan orang sekitar yang mampu memacu siswa.

Banyak faktor luar yang dapat menjadikan proses belajar menjadi lebih efektif. Suasana belajar yang santai dan menyenangkan, penggunaan metode pembelajaran yang bervariasi, dan dengan menciptakan persaingan dan kerjasama telah terbukti dapat meningkatkan motivasi belajar siswa (Suharni \& Purwanti, 2018).

Aktivitas belajar merupakan aktivitas yang memiliki tingkat kesulitan tersendiri bagi setiap individu. Aktivitas ini tidak selamanya dapat berlangsung dengan baik. Terkadang berjalan dengan lancar dan terkadang tidak, terkadang dapat cepat menangkap apa yang dipelajari, dan terkadang terasa sulit menangkap apa yang dipelajari. Dalam hal semangat terkadang semangatnya tinggi, namun sulit meningkatkan konsentrasi. Hal tersebut, merupakan kenyataan yang sering dijumpai pada setiap siswa dalam proses belajar mengajar. Setiap individu memang tidak ada yang sama.

Siswa dan anak-anak di Desa Juwiran pada dasarnya memiliki semangat belajar yang tinggi. Semangat tersebut tercermin dari banyaknya rasa ingin tahu akan materi yang disampaikan di sekolah. Prestasi belajar yang dicapai siswa merupakan sebuah tolak ukur maksimal yang telah dicapai oleh siswa setelah mengikuti kegiatan pembelajaran selama waktu yang telah ditentukan secara bersama (Juliani, Mustadi, \& Lisnawati, 2020). Akan tetapi tidak bisa dipungkiri bahwa tinggi rendahnya prestasi siswa banyak dipengaruhi oleh faktor lain diluar proses belajar mengajar itu sendiri (Suharsimi, 2006)

Bimbingan merupakan proses pemberian bantuan yang diberikan kepada individu agar mampu mencapai tingkat perkembangan diri yang optimal. Pengertian bimbingan banyak dikemukakan oleh para ahli seperti (Winkel, 2004) yang mendefinisikan bimbingan sebagai sebuah kegiatan pemberian bantuan kepada seseorang atau sekelompok orang dalam membuat suatu pilihan secara bijaksana dan dalam mengadakan penyesuaian diri terhadap tuntutan hidup yang ada. Sesuai dengan yang dinyatakan Prayitno (2004) bahwa bimbingan adalah bantuan yang diberikan kepada seseorang atau suatu kelompok supaya mereka dapat berkembang menjadi pribadi yang mandiri.

Winkel (2004) menyatakan belajar adalah semua aktivitas yang berlangsung dan terjadi di dalam interaksi aktif pada lingkungan, yang menghasilkan perubahan dalam pengelolaan pemahaman siswa. Adapun Kartono (2003), menyatakan belajar merupakan sebuah proses atau perbuatan yang dilakukan dengan sengaja, kemudian menimbulkan perubahan, dimana keadaannya berbeda dari perubahan yang lainnya. Sifat perubahannya tidak akan terjadi seperti semula sebelum kegiatan dilaksanakan atau bersifat relative permanent. Hal ini tidak bisa diterapkan pada perubahan akibat situasi sesaat, seperti perubahan akibat kecelakaan, sakit, dan mabuk.

Munandir (2003) mengungkapkan bimbingan belajar adalah sebuah proses pemberian bimbingan dari pembimbing, baik guru maupun pembimbing lain kepada siswa dengan cara mengembangkan suasana belajar yang kondusif dan mengembangkan keterampilan serta kebiasaan belajar supaya dapat mencapai hasil belajar yang maksimal sesuai dengan bakat dan kemampuan yang dimiliki siswa.

Berdasarkan uraian di atas, dapat disimpulkan bahwa bimbingan belajar adalah sebuah proses pemberian bantuan dalam bentuk pengajaran kepada siswa dalam menyelesaikan masalah-masalah belajar yang dihadapi siswa, sehingga tujuan belajar yang baik akan tercapai.

Beberapa manfaat kegiatan bimbingan belajar yang dilakukan diluar sekolah telah banyak dibuktikan. Dengan mengikuti bimbingan belajar, secara alami jam belajar siswa akan lebih banyak sehingga dapat berpengaruh secara langsung pada peningkatan nilai belajar siswa (Nurlinggasari, 2017). Selain itu ditambah dengan menggunakan cara penyampaian materi yang menarik oleh pembimbing yang ramah dan humoris, siswa dapat lebih cepat memahami materi yang ada (Barus, 2016).

Dari sisi lain, melalui pendekatan secara lebih personal yang dilakukan saat bimbingan belajar juga dapat membantu siswa lebih cepat memahami pelajaran. Hal ini penting karena di sekolah sering kali terjadi diskriminasi visual, dimana posisi duduk siswa yang berada di bagian bangku paling belakang menjadikan 
siswa menjadi kurang jelas dalam memperhatikan guru saat menjelaskan materi (Abdullah, 2016).

Selain berpengaruh positif terhadap nilai siswa, bimbingan belajar juga dapat berdampak baik bagi tingkat kepercayaan diri siswa. Siswa yang mengikuti bimbingan belajar di luar sekolah akan lebih percaya diri dalam mengikuti kegiatan belajar yang dilakukan di sekolah, sehingga dapat lebih aktif di kelas (Noor \& Ulfa, 2016).

Oleh sebab itu akan banyak manfaat yang dapat diperoleh siswa ketika bergabung pada bimbingan belajar yang di adakan oleh KKN-Dik FKIP UMS di MIM Juwiran. Keterbatasan waktu di sekolah dapat membuat siswa tak leluasa bertanya kepada guru mengenai materi pelajaran yang belum dipahami. Melalui bimbingan belajar di posko KKN-Dik FKIP UMS siswa dapat dengan leluasa menanyakan materi yang belum dipahami.

Berdasarkan hal tersebut, penulis yang melakukan kegiatan pengabdian KKN-Dik FKIP UMS di Desa Juwiran mengadakan kegiatan bimbingan belajar yang bertujuan untuk memberikan dorongan eksternal untuk siswa agar tercapai prestasi akademik yang lebih baik.

\section{Metode Pelaksanaan}

Sasaran pengabdian ini yaitu siswa sekolah tingkat dasar atau SD. Desa Juwiran memiliki jumlah anak usia SD cukup banyak sehingga kegiatan pengabdian dapat berjalan dengan lancar dan penuh dengan dukungan. Sebagian besar siswa berasal dari lokasi penulis melaksanakan program KKN-Dik FKIP UMS yaitu Madrasah Ibtidaiyyah Muhammadiyah (MIM) Juwiran, yang berada di Desa Juwiran, Kecamatan Juwiring, Kabupaten Klaten. Sebagian kecil lainnya berasal dari madrasah dan SD lain di desa tersebut

Metode yang digunakan untuk mengatasi permasalahan kurangnya dorongan eksternal terhadap proses belajar siswa adalah dengan metode pembimbingan (Ishartono, Alfian, \& Firdaus, 2016). Metode pembimbingan dilakukan dengan cara pemberian bantuan bimbingan belajar dan konsultasi tentang permasalahan yang dihadapi siswa dalam proses belajar maupun kehidupan mereka di sekolah maupun dirumah.

Dalam kegiatan bimbingan belajar, mahasiswa menggunakan berbagai sumber seperti prior knowledge serta sumber yang terdapat di buku maupun internet untuk memberikan bimbingan kepada siswa secara optimal.
Selain memberikan bimbingan belajar, mahasiswa juga memberikan layanan konsultasi secara personal terkait keseharian siswa yang mungkin bisa menjadi salah satu faktor yang mempengaruhi hasil belajar mereka.

Kegiatan dilakukan dengan pendekatan kepada siswa guna memperoleh hubungan yang baik antara mahasiswa dan siswa di Desa Juwiran sehingga dapat tercipta suasana belajar yang menyenangkan.

Pelaksanaan kegiatan bimbingan belajar dilakukan di Posko KKNDiK yang berada tidak jauh dari lokasi MIM Juwiran pada setiap hari Senin hingga Jum'at dimulai pukul 18.30 hingga pukul 20.30. Waktu tersebut disesuaikan dengan kesepakatan dengan siswa dan orang tua siswa dan dirasa paling tepat karena siswa usia SD masih banyak membutuhkan waktu bermain terutama pada akhir pekan.

\section{Hasil Pelaksanaan dan Pembahasan}

Kegiatan bimbingan belajar merupakan salah satu program yang efektif guna mendorong siswa untuk memperoleh hasil belajar secara maksimal di sekolah dengan cara menanamkan kebiasaan untuk rutin belajar dan tekun dalam mengerjakan tugas (Munandir, 2003)

Layanan bimbingan belajar perlu diterapkan guna mengembangkan sikap dan kebiasaan belajar siswa serta meningkatkan hasil belajar semaksimal mungkin sesuai dengan kapasitas belajar siswa. Belajar di sini dimaksudkan tidak hanya berkaitan dengan mata pelajaran yang diajarkan di sekolah, melainkan menyangkut pengembangan keseluruhan pribadi masing-masing siswa secara utuh.

Seperti kebanyakan anak pada usianya, siswa tingkat SD di Desa Juwiran ini selepas pulang sekolah, melakukan aktivitasnya sendiri-sendiri, seperti bermain bersama teman sejawat ataupun beristirahat di rumah masing-masing. Dari hasil wawancara yang dilakukan dengan beberapa siswa saat penulis pertama datang di lokasi pengabdian, didapati bahwa tidak ada siswa yang sedang mengikuti kegiatan bimbingan belajar sepulang sekolah. Padahal kebanyakan dari mereka mengaku masih mengalami kesulitan untuk memahami materi yang telah disampaikan oleh guru di saat masuk sekolah. Selain itu didapati pula bahwa bimbingan belajar yang pernah mereka ikuti selama ini kurang berjalan dengan efektif karena berbagai hal, salah satunya adalah kondisi bimbingan belajar yang kurang menyenangkan. 
Hasil dari pengamatan dan pengabdian yang penulis laksanakan di Desa Juwiran menunjukkan bahwa siswa-siswi yang ada di desa tersebut memiliki ketertarikan dengan adanya kegiatan bimbingan belajar yang bisa digunakan untuk membantu menyelesaikan tugas-tugas sekolah. Hal tersebut terlihat dari tingginya antusias siswa dimulai dari hari pertama KKN-Dik FKIP UMS dimulai dengan total pelaksanaan kegiatan bimbingan belajar selama 6 minggu penuh setiap hari Senin sampai Jumat. Dalam satu sesi bimbingan belajar (kurang lebih 2-3 jam) rata-rata ada 18 orang siswa yang mengikutinya.

Kegiatan bimbingan belajar yang dilaksanakan penulis di Desa Juwiran ini dapat dikatakan membawa dampak positif bagi siswa dan mahasiswa pelaksananya. Kegiatan bimbingan belajar ini dilaksanakan secara terjadwal sehingga tidak mengganggu aktivitas siswa lainnya, dan juga tidak mengurangi waktu bermain siswa, karena anak-anak seusia SD masih memiliki kecenderungan untuk bermain yang dapat berdampak positif terhadap aspek sosialnya (Hadini, 2013).

Bagi mahasiswa pelaksana kegiatan, salah satu manfaat nyata adalah bertambahnya pengetahuan tentang karakter belajar siswa SD dimana aspek menyenangkan atau tidaknya kondisi saat belajar berpengaruh sangat besar bagi siswa. Oleh sebab itu saat melakukan pembelajaran dalam kegiatan bimbingan belajar yang dilakukan, mahasiswa mendesain cara penyampaian materinya yang menyenangkan, semisal dengan perumpamaan-perumpamaan yang konyol, dengan bahasa yang mudah dipahami anak-anak dan juga intonasi bicara yang santai.

Selain itu, mahasiswa juga mendapat pengaruh positif lainnya, yaitu menjadi lebih terlatih dalam menjadi seorang pengajar, terutama mata pelajaran yang berkaitan dengan bidang studi yang ditempuh di perguruan tinggi. Hal ini dapat bermanfaat bagi kehidupan mahasiswa, khususnya di dunia kerja setelah lulus dari perguruan tinggi.

Manfaat bagi siswa yang mengikuti kegiatan bimbingan belajar ini salah satunya dapat membantu siswa dalam memecahkan masalah yang mereka hadapi di sekolah, khususnya dalam menyelesaikan tugas dari guru mata pelajaran yang diberikan di sekolah. Hal ini terlihat dari hasil atau nilai tugas semua siswa yang mengikuti kegiatan bimbingan belajar, dimana semuanya mendapat nilai tugas yang baik. Selain itu dengan mengikuti kegiatan ini siswa merasa dimudahkan dalam mengikuti kegiatan belajar di sekolah untuk semua mata pelajaran, karena selain membahas tugas sekolah, dalam kegiatan yang dilakukan secara rutin dibahas review untuk materimateri yang akan diajarkan di sekolah untuk pertemuan selanjutnya.

Dampaknya adalah meningkatnya tingkat percaya diri siswa dalam mengikuti pembelajaran di sekolah karena mereka memiliki bekal yaitu pemahaman materi sebelum pembelajaran dilaksanakan, dibuktikan dengan siswa peserta bimbingan belajar yang lebih aktif menjawab pertanyaan guru di kelas ataupun saat guru memberikan kesempatan siswa untuk mengerjakan soalsoal di papan tulis kelas.

Bimbingan belajar yang menyenangkan juga merupakan bentuk kegiatan pembelajaran yang dapat membantu memberikan bantuan kepada siswa agar bersemangat untuk meningkatkan prestasi belajar atau hasil belajar menjadi lebih baik lagi. Dengan kegiatan yang dilakukan di Desa Juwiran ini, siswa terlihat sangat bersemangat dalam mengerjakan tugas yang guru berikan karena merasa mendapat tambahan semangat dari mahasiswa KKN-Dik FKIP UMS. Pemberian semangat dari luar diri siswa dapat berpengaruh besar pada kondisi psikologis siswa sebagai seorang pelajar yang fokus utamanya adalah belajar dan memahami materi pelajaran di sekolah.

Oleh karena itu, kegiatan pengabdian di bidang pendidikan yang dilaksanakan salam program KKN-Dik di Desa Juwiran ini sangat berdampak positif bagi psikologis dan akademis siswa. Dampak psikologis dari segi semangat belajar dan rasa percaya diri siswa, sedangkan dampak akademis dari hasil belajar siswa di sekolah baik dalam performa atau keaktifan siswa di dalam kelas maupun nilai tugas yang lebih baik.

\section{Simpulan}

Kegiatan bimbingan belajar yang dilakukan di MIM Juwiran ini merupakan sebuah kegiatan pembelajaran yang bertujuan untuk membantu siswa dalam meningkatkan prestasi atau hasil belajar siswa dan juga bertujuan untuk meningkatkan tingkat kepercayaan diri siswa saat mengikuti kegiatan pembelajaran di sekolah. Siswa-siswi yang ada di Desa Juwiran sangat antusias dan senang dalam mengikuti kegiatan bimbingan belajar yang dilaksanakan, peserta yang mengikuti kegiatan bimbingan belajar juga cukup banyak. Dengan adanya rasa ingin 
tahu yang tinggi, didukung dengan motivasi yang diberikan melalui kegiatan bimbingan belajar, siswa dan anak-anak SD yang ada di Desa Juwiran menjadi memiliki semangat belajar yang lebih tinggi, dibuktikan dari meningkatnya keaktifan siswa saat mengikuti kegiatan pembelajaran di sekolah. Selain faktor internal, seperti kemauan siswa; faktor eksternal, seperti guru, orang tua, sekolah, lingkungan sekitar juga sangat berperan penting sebagai salah satu pendukung dalam meningkatkan prestasi siswa. Jika kedua faktor tersebut dapat diperoleh siswa dengan baik, maka siswa akan mendapat banyak hal positif selama pembelajaran, baik di rumah maupun di sekolah dengan hasil belajar yang lebih baik atau meningkat.

\section{Daftar Pustaka}

Abdullah, D. (2016). Bimbingan Belajar Bagi Siswa Berkesulitan Membaca. JURNAL SULOH: Jurnal Bimbingan Konseling FKIP Unsyiah, 1(1).

Barus, T. A. B. (2016). Perbandingan Hasil Belajar Biologi Siswa Yang Mengikuti Bimbingan Belajar Dengan Siswa Yang Tidak mengikuti Bimbingan Belajar. Jurnal Pelita Pendidikan, 4(2), 135-141.

Hadini. (2013). Psikologi subjek didik dalam pandangan ibnu sina. Jurnal.Ar-Raniry, 3, 264281. https://doi.org/10.22373/jm.v3i2.192

Ishartono, N., Alfian, I. A., \& Firdaus, N. (2016). Pelatihan Penggunaan Software Geogebra Pada Materi Bangun Ruang Dimensi Tiga Untuk GuruGuru Matematika Sekolah Menengah Muhammadiyah Se-Sukoharjo. The 4th University Research Coloquium 2016, 264-270. https://doi.org/http://hdl.handle.net/11617/7705

Juliani, A., Mustadi, A., \& Lisnawati, I. (2020). "Make A Match Model" for Improving the Understanding of Concepts and Student Learning Results. Indonesian Journal on Learning and Advanced Education (IJOLAE), 3(1), 48-56. https://doi.org/10.23917/ijolae.v3i1.10269

Kartono, K. (2003). Bimbingan dan Dasar-dasar
Pelaksanaannya. Jakarta: Rajawali Bina Aksara. Munandir. (2003). Program Bimbingan Karier di Sekolah.

Noor, R. A., \& Ulfa, R. M. (2016). Persepsi Siswa SMA Negeri 1 Pontianak Terhadap Lembaga Bimbingan Belajar. Jurnal Pendidikan Dan Pembelajaran Khatulistiwa, 5(7).

Nurlinggasari, D. (2017). Hubungan Bimbingan Belajar di Luar Sekolah dan Motivasi dengan Prestasi Belajar Biologi. Jurnal Bioterdidik, 5(7).

Prayitno. (2004). Layanan Bimbingan dan Konseling Kelompok. Jakarta: Gahlia Indonesia.

Rasam, F., Interdiana, A., Sari, C., Program, D., Pendidikan, S., Universitas, E., ... Kunci, K. (2018). Peran Kreativitas guru dalam penggunaan media belajar. Research and Development Journal Of Education, 5(1), 95-113.

Sabardila, A., Fachri, A. R., Santoso, E., Aini, N. N., Safitri, M., Putri, D. M., ... Safira, R. (2020). Peningkatan Antusiasme dan Pemahaman Siswa dalam PBM melalui Metode Talking Stick di MIM Jatisari Kedungdowo, Boyolali. Buletin KKN Pendidikan, 1(2), 56-62. https://doi.org/10.23917/bkkndik.v1i2.10765

Suharni, \& Purwanti. (2018). Upaya Meningkatkan Motivasi Belajar Siswa. G-Couns: Jurnal Bimbingan Dan Konseling, 3(1), 131-145.

Suharsimi, A. (2006). Prosedur penelitian suatu pendekatan praktik. Jakarta: Rineka Cipta.

Winkel, W. S. (2004). Bimbingan dan konseling di Institut Pendidikan. Jakarta: Grasindo. 